\title{
Aetiology of suppurative corneal ulcers in Ghana and south India, and epidemiology of fungal keratitis
}

\author{
A K Leck, P A Thomas, M Hagan, J Kaliamurthy, E Ackuaku, M John, M J Newman, \\ F S Codjoe, J A Opintan, C M Kalavathy, V Essuman, C A N Jesudasan, G J Johnson
}

Br J Ophthalmol 2002;86:1211-1215

Series editors: W V Good and S Ruit

See end of article for authors' affiliations

......................

Correspondence to: Dr Astrid K Leck,

Department of Infectious and Tropical Diseases,

Clinical Research Unit,

London School of Hygiene and Tropical Medicine,

Keppel Street, London

WCIE 7HT, UK ;

a.leck@ucl.ac.uk

Accepted for publication 19 July 2002
Background: A multicentre study was carried out in Ghana and southern India to determine the aetiology of suppurative keratitis in two regions located at similar tropical latitudes. Studies of fungal keratitis from the literature were reviewed.

Methods: Patients presenting at rural and urban eye units with suspected microbial keratitis were recruited to the study. Corneal ulceration was defined as loss of corneal epithelium with clinical evidence of infection with or without hypopyon. Microscopy and culture were performed on all corneal specimens obtained.

Results: 1090 patients were recruited with suspected microbial keratitis between June 1999 and May 2001. Overall the principal causative micro-organisms in both regions were filamentous fungi (42\%): Fusarium species and Aspergillus species were the commonest fungal isolates. Pseudomonas species were most frequently isolated from cases of bacterial keratitis in Ghana but in India the commonest bacterial isolates were streptococci.

Conclusion: Infections of the cornea due to filamentous fungi are a frequent cause of corneal damage in developing countries in the tropics and are difficult to treat. Microscopy is an essential tool in the diagnosis of these infections. A knowledge of the "local" aetiology within a region is of value in the management of suppurative keratitis in the event that microscopy cannot be performed.
S carring of the cornea as a result of suppurative keratitis is an important cause of preventable blindness. In some developing countries in the tropics, corneal infections are the second commonest cause of blindness after unoperated cataract. $^{1-3}$ Suppurative corneal ulcers may be caused by bacteria, fungi, and protozoa. However, within the tropics, as many as two thirds of ulcers may be due to filamentous fungi. This type of ulceration is commonly associated with ocular trauma. ${ }^{2-9}$

Untreated, suppurative keratitis may lead to opacification and, ultimately, to perforation of the cornea. The associated morbidity is the result of several factors and is directly affected by difficulties in patient management because of a lack of diagnostic facilities and appropriate treatment. Specific treatment requires prompt and accurate identification of the causative micro-organisms. ${ }^{10}$ Within the setting of rural eye hospitals in the tropics laboratory facilities are rare and diagnosis is based on clinical characteristics. As a direct result of this, treatment is often empirical.

The microbial causes of suppurative keratitis vary considerably between continents and countries and also within countries. It is essential to determine the local aetiology within a given region when planning a corneal ulcer management strategy. Several studies have investigated the epidemiology of corneal ulceration, causative micro-organisms, and effective treatments, particularly in the Indian subcontinent. However there is a paucity of information in the literature with regard to the experience in African countries. ${ }^{6-811-14}$

The following study was conducted at hospitals in Ghana and India to compare the aetiology of suppurative keratitis in two countries, in different continents, at similar tropical latitudes. The aims of this investigation were to improve facilities for laboratory diagnosis, to determine the predominant causative micro-organisms, to identify the most suitable treatments, and encourage rapid referral of patients.

\section{MATERIALS AND METHODS \\ Patients}

A prospective study of suppurative keratitis was conducted in Ghana and southern India between June 1999 and May 2001. Patients were recruited at the eye unit of Korle Bu Teaching Hospital in Accra, Ghana, and also at two rural hospitals in Agogo (Ashanti region) and Bawku (Upper East region). In India, patients who presented with suppurative keratitis at two rural "taluk" hospitals in the Tiruchirapalli district of the southern state of Tamil Nadu were included in the study in addition to patients from the main study centre, Joseph Eye Hospital (JEH) base hospital.

All patients presenting with suspected suppurative keratitis were included in the study. Corneal ulceration was defined as loss of corneal epithelium with underlying stromal infiltrate and suppuration associated with signs of inflammation, with or without hypopyon. ${ }^{7}$ Patients with suspected or confirmed viral keratitis were excluded from the study. Patient consent was mandatory for inclusion in the study.

\section{Clinical examination and laboratory investigation}

Each patient was examined at the slit lamp; clinical features were noted and a drawing made for patient records. A corneal scrape was performed by an ophthalmologist using a sterile 21 gauge needle, or blunt Kimura spatula, following the instillation of local anaesthetic (amethocaine hydrochloride $0.5 \%$, without preservative). In India, lignocaine (lidocaine) $4 \%$ was routinely administered, anaesthetic without preservative was sometimes used. If a patient was taking antibiotics at the time of presentation to the clinic treatment was stopped and investigations were delayed for 24 hours.

Corneal material obtained from scraping the ulcer was smeared onto two slides which were stained with Gram stain and lactophenol cotton blue mountant for microscopic examination. Material was inoculated directly onto 5\% sheep's blood agar, Sabouraud glucose agar, and into Sabouraud broth. In India, inhibitory mould agar (IMA) was substituted 
Table 1 Aetiology of corneal ulcers

\begin{tabular}{|c|c|c|c|c|}
\hline \multirow[b]{2}{*}{ Type of micro-organism } & \multicolumn{2}{|c|}{ India } & \multicolumn{2}{|c|}{ Ghana } \\
\hline & No & $\%$ & No & $\%$ \\
\hline Definite bacterial & 191 & 23.9 & 36 & 12.4 \\
\hline Definite fungal & 309 & 38.6 & 105 & 36.2 \\
\hline Definite mixed & 44 & 5.5 & 4 & 1.4 \\
\hline Definite Acanthamoeba spp & 7 & 0.9 & 1 & 0.3 \\
\hline Unknown & 249 & 31.1 & 144 & 49.7 \\
\hline \multirow[t]{2}{*}{ Total } & 800 & 100 & 290 & 100 \\
\hline & \multicolumn{2}{|c|}{ India } & \multicolumn{2}{|c|}{ Ghana } \\
\hline Microscopy and culture negative & & \multicolumn{2}{|l|}{87} \\
\hline Microscopy positive, culture negative * & \multicolumn{2}{|l|}{218} & \multicolumn{2}{|l|}{24} \\
\hline Microscopy negative, culture positive & & \multicolumn{2}{|l|}{33} \\
\hline Total & \multicolumn{2}{|l|}{249} & \multicolumn{2}{|l|}{144} \\
\hline
\end{tabular}

for Sabouraud glucose agar, as was routine practice of the laboratory. At the tertiary centres, if there was sufficient corneal material, additional culture media were inoculated (brain heart infusion (BHI) broth, chocolate agar, and cysteine tryptone agar). Blood agar plates, cystine tryptone agar, and $\mathrm{BHI}$ broth were incubated at $37^{\circ} \mathrm{C}$. Sabouraud glucose agar plates, Sabouraud broth, and IMA plates were incubated at $27^{\circ} \mathrm{C}$. A non-nutrient agar plate was inoculated if Acanthamoeba keratitis was suspected and an additional slide was prepared for microscopy.

Bacteria were further identified using routine biochemical identification tests and selective media. Identification of fungi was carried out in London and at the Mycology Reference Laboratory, Bristol, in addition to the overseas centres. Filamentous fungi were identified according to the macroscopic appearance of cultures on Sabouraud glucose, potato dextrose and cornmeal agars, and microscopic appearance of conidia and spore bearing structures. Yeasts were identified to species level using the germ tube test (incubation for 1.5 hours, at $37^{\circ} \mathrm{C}$, in horse serum), Auxacolor and API kits (Bio Mérieux).

Microbial cultures were considered to be significant if growth of the same organism could be demonstrated on two or more solid phase cultures. Similarly, if there was semiconfluent

\begin{tabular}{|c|c|c|c|c|}
\hline \multirow[b]{2}{*}{ Bacteria } & \multicolumn{2}{|l|}{ India } & \multicolumn{2}{|c|}{ Ghana } \\
\hline & No & $\%$ & No & $\%$ \\
\hline \multicolumn{5}{|l|}{ Gram positive cocci } \\
\hline Streptococcus spp & 110 & 46.8 & 8 & 20.0 \\
\hline (Streptococcus pneumoniae) & (62) & (26.4) & (6) & $(15.0)$ \\
\hline Staphylococcus aureus & 5 & 2.1 & 2 & 5.0 \\
\hline Coagulase -ve staphylococci & 58 & 24.7 & 2 & 5.0 \\
\hline Micrococcus spp & - & - & 1 & 2.5 \\
\hline \multicolumn{5}{|l|}{ Gram positive bacilli } \\
\hline Bacillus spp & 2 & 0.9 & - & - \\
\hline Corynebacterium spp & - & - & 4 & 10.0 \\
\hline Nocardia spp & 3 & 1.3 & - & - \\
\hline \multicolumn{5}{|l|}{ Gram negative bacilli } \\
\hline $\begin{array}{l}\text { Pseudomonas spp } \\
\text { (Pseudomonas aeruginosa) }\end{array}$ & $\begin{array}{l}35 \\
(33)\end{array}$ & $\begin{array}{l}14.9 \\
(14.0)\end{array}$ & 21 & 52.5 \\
\hline Acinetobacter spp & 11 & 4.7 & - & - \\
\hline Enterobacter spp & 3 & 1.3 & - & - \\
\hline Citrobacter spp & 1 & 0.4 & - & - \\
\hline Aeromonas spp & 5 & 2.1 & - & - \\
\hline Klebsiella spp & 2 & 0.9 & - & - \\
\hline Unidentified & - & - & 2 & 5.0 \\
\hline Totals & 235 & 100 & 40 & 100 \\
\hline
\end{tabular}

Table 3 Identification of fungi isolated from corneal tissue of patients with suppurative keratitis

\begin{tabular}{|c|c|c|c|c|}
\hline \multirow[b]{2}{*}{ Fungi } & \multicolumn{2}{|l|}{ India } & \multicolumn{2}{|c|}{ Ghana } \\
\hline & No & $\%$ & No & $\%$ \\
\hline Fusarium spp & 141 & 39.9 & 46 & 42.2 \\
\hline Aspergillus spp & 76 & 21.5 & 19 & 17.4 \\
\hline A flavus & 59 & (16.7) & 9 & (8.3) \\
\hline A fumigatus & 15 & (4.2) & 7 & (6.4) \\
\hline A niger & 1 & (0.3) & 1 & (0.9) \\
\hline A nidulans & - & - & 1 & (0.9) \\
\hline Aspergillus spp & 1 & (0.3) & 1 & (0.9) \\
\hline Cuvularia spp & 34 & 9.6 & 1 & 0.9 \\
\hline Lasiodiplodia theobromae & 1 & 0.3 & 6 & 5.5 \\
\hline Paecilomyces spp & - & - & 1 & 0.9 \\
\hline Penicillium spp & 2 & 0.6 & - & - \\
\hline Scedosporium apiospermum & 2 & 0.6 & 2 & 1.8 \\
\hline Cephaliophora irregularis & 1 & 0.3 & - & - \\
\hline Cladosporium cladosporoides & - & - & 1 & 0.9 \\
\hline Cylindrocarpon spp & 1 & 0.3 & - & - \\
\hline Exserohilum rostratum & 1 & 0.3 & - & - \\
\hline Bipolaris spp & 2 & 0.6 & - & - \\
\hline Candida spp & - & - & 1 & 0.9 \\
\hline Unidentified & 35 & 9.9 & 5 & 4.6 \\
\hline Suspected, but culture negative & 57 & 16.1 & 27 & 24.8 \\
\hline Totals & 353 & 100 & 109 & 100 \\
\hline
\end{tabular}

growth at the site of inoculation or growth on one solid medium consistent with microscopy (that is, appropriate staining and morphology with Gram stain); or semiconfluent growth at the site of inoculation on one solid medium (if bacteria); or growth of the same organism on repeated scraping. ${ }^{1{ }^{15} 16}$ If, by microscopy, hyphae were observed in corneal tissue, but failed to grow in culture, the causative organism was reported as fungal.

\section{RESULTS}

A total of 1090 patients presenting with suppurative keratitis were enrolled in the study; 290 in Ghana and 800 in India. One patient from Ghana and one patient from India presented with bilateral infection. Fungi were identified as the dominant causative agent of infection (including mixed infections): $44 \%$ in southern India and $37.6 \%$ in Ghana. Bacteria were isolated from $29.3 \%$ of cases in south India and $13.8 \%$ in Ghana (Table 1). In each case of mixed infection a single bacterial species was associated with a single fungal species. This study revealed a higher percentage of "mixed" infections in India than Ghana: $5.5 \%$ versus $1.4 \%$.

Seven patients presented with suppurative keratitis due to infection with Acanthamoeba species in south India. The first reported case of Acanthamoeba keratitis in Ghana was diagnosed during this study ( $B J O$, accepted for publication). None of these patients were contact lens wearers.

In India 249 (31\%) cases had no definitive laboratory diagnosis; Gram positive cocci were reported from the microscopy in $80 \%(200 / 249)$ of these cases; however, cultures were negative. It was not possible to determine the aetiological agent of $144(50 \%)$ corneal ulcer cases in Ghana (Table 1). Microscopy and culture results were negative in $60 \%$ (87/144) of cases. Scanty bacteria were seen in $14 \%$ (24) of Gram stained smears. Of the remaining 33 cases which were microscopy negative, filamentous fungi were isolated in culture from $51 \%$ cases and bacteria from $49 \%$ cases but growth was not considered to be significant, using the criteria stated (see Materials and methods).

Pseudomonas species were the commonest bacterial isolates from corneal ulcers in Ghana (52.5\%); P aeruginosa being the commonest reported species. Streptococci (20\%) and staphylococci $(10 \%)$ were commonly associated with corneal infection (Table 2). In India streptococci accounted for $46.8 \%$ 
Table 4 Mycotic keratitis: a review of the literature

\begin{tabular}{|c|c|c|c|c|c|c|}
\hline Place & Reference & Year & Number cases & $\%$ Fungi* & Organism 1 & Organism 2 \\
\hline \multicolumn{7}{|l|}{ Europe } \\
\hline London & Coster $^{17}$ & 1981 & 67 & $3 \%$ & \multirow{3}{*}{$\begin{array}{l}2 \text { cases only } \\
\text { Candida spp 58\% }\end{array}$} & \\
\hline London, UK & Personal comm & 2001 & 72 & $3 \%$ & & Aspergillus spp $26 \%$ \\
\hline Sweden & Neumann ${ }^{18}$ & 1993 & 48 & $0 \%$ & & \\
\hline \multicolumn{7}{|l|}{ North America } \\
\hline Florida & Liesegang ${ }^{19} \dagger$ & 1980 & 663 & \multirow[t]{3}{*}{$20 \%$} & \multirow{2}{*}{$\begin{array}{l}\text { Fusarium spp } 62 \% \\
\text { Fusarium spp } 62 \%\end{array}$} & \multirow{2}{*}{$\begin{array}{l}\text { Candida spp } 7.5 \% \\
\text { Candida spo } 12.5 \%\end{array}$} \\
\hline Florida & $\operatorname{Rosa}^{20}$ & 1994 & 125 & & & \\
\hline Philadelphia & Tanure ${ }^{21}$ & 2000 & 24 & & \multirow{2}{*}{$\begin{array}{l}\text { Calbicans } 46 \% \\
\text { Calbicans } 4 \%\end{array}$} & Fusarium spp $25 \%$ \\
\hline California & Ormerod $^{22} \dagger$ & 1987 & 227 & \multirow{2}{*}{$\begin{array}{l}11 \% \\
32 \%\end{array}$} & & Penicillium spp 2\% \\
\hline Atlanta & Harris $^{23}$ & 1988 & 108 & & \multicolumn{2}{|l|}{ Candida spp $94 \%$} \\
\hline Northern USA & \multirow{2}{*}{$\mathrm{O}^{\prime} \mathrm{Day}^{24}$} & \multirow[t]{2}{*}{1987} & 33 & & \multirow{2}{*}{$\begin{array}{l}\text { Candida spp } 42 \% \\
\text { Fusarium spp } 55 \%\end{array}$} & \multirow{2}{*}{$\begin{array}{l}\text { Aspergillus spp } 30 \% \\
\text { Candida spp } 9.5 \%\end{array}$} \\
\hline Southern USA & & & 285 & & & \\
\hline \multicolumn{7}{|l|}{ South America } \\
\hline Paraguay & Mino de Kaspar ${ }^{25}$ & 1991 & 26 & $58 \%$ & Fusarium spp $42 \%$ & Aspergillus spp $19 \%$ \\
\hline \multicolumn{7}{|l|}{ The Middle East } \\
\hline Saudi Arabia & Khairallah ${ }^{26}$ & 1992 & 191 & $14 \%$ & Aspergillus spp $41 \%$ & $\begin{array}{l}\text { Fusarium spp } \ddagger \\
\text { Candida albicans } \ddagger\end{array}$ \\
\hline \multicolumn{7}{|r|}{ 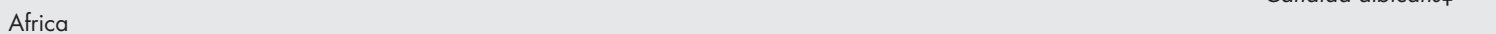 } \\
\hline Ghana (Accra) & $\operatorname{Hagan}^{6} \dagger$ & 1995 & 199 & $34 \%$ & Fusarium spp 52\% & \multirow[t]{2}{*}{ Aspergillus spp $15 \%$} \\
\hline South Africa & Carmichael $^{27}$ & 1985 & 274 & $2 \%$ & Curvularia spp $33 \%$ & \\
\hline Nigeria & Gugani ${ }^{11}$ & 1976 & 59 & & Fusarium spp $36 \%$ & Penicillium spp $29 \%$ \\
\hline Tanzania & Mselle $^{28}$ & 1999 & 212 & $15 \%$ & Fusarium spp $75 \%$ & Aspergillus spp $19 \%$ \\
\hline South Africa & Ormerod $^{29}$ & 1987 & 120 & $2.5 \%$ & 3 different isolates & \\
\hline \multicolumn{7}{|l|}{ Asia } \\
\hline Nepal, Dharan & Khanal $^{9} \dagger$ & 2001 & 86 & $44 \%$ & Aspergillus spp $60 \%$ & Fusarium spp $13 \%$ \\
\hline Nepal, Kathmandu & Upadhyay' & 1991 & 405 & $17 \%$ & Aspergillus spp $47 \%$ & Candida spp 13\% \\
\hline Nepal & Chaudhary ${ }^{30}$ & 1999 & 110 & $8 \%$ & \\
\hline Bangladesh & $\operatorname{Rahman}^{31}$ & 1998 & 63 & & \multicolumn{2}{|l|}{ Aspergillus spp 35\% } \\
\hline Bangladesh & Dunlop ${ }^{4}$ & 1994 & 66 & $36 \%$ & Aspergillus spp $40 \%$ & Fusarium spp $21 \%$ \\
\hline Bangladesh & Williams $^{32} \dagger$ & 1991 & 127 & $34 \%$ & Aspergillus spp $49 \%$ & Fusarium spp $28 \%$ \\
\hline Bangladesh & Williams ${ }^{33} \dagger$ & 1987 & 33 & $21 \%$ & Aspergillus spp $29 \%$ & Fusarium spp $14 \%$ \\
\hline India, North & Chander $^{34}$ & 1994 & 730 & $8.4 \%$ & Aspergillus spp $40 \%$ & Fusarium spp $16 \%$ \\
\hline India, New Delhi & Panda (children) ${ }^{8}$ & 1997 & 211 & $10.8 \%$ & Aspergillus spp $40 \%$ & Fusarium spp $11 \%$ \\
\hline India, New Delhi & Mahajan $^{35}$ & 1985 & 674 & $19.7 \%$ & Aspergillus spp $37 \%$ & Fusarium spp $10 \%$ \\
\hline India, Mumbai & Deshpande ${ }^{13} \dagger$ & 1999 & 367 & & Aspergillus spp $60 \%$ & Candida spp $10 \%$ \\
\hline India, Hyderabad & Kunimoto $^{16} \dagger$ & 2000 & 102 & $19 \%$ & Aspergillus spp $37 \%$ & Curvularia spp $16 \%$ \\
\hline India, Hyderabad & Garg $^{14}$ & 2000 & 557 & & Fusarium spp $38 \%$ & Aspergillus spp $30 \%$ \\
\hline India, Karnataka & Kotigadde $^{36}$ & 1992 & 295 & $23 \%$ & Aspergillus spp $34 \%$ & Candida spp $19 \%$ \\
\hline India, Madras & Sudaram ${ }^{37}$ & 1989 & 150 & $45 \%$ & Aspergillus spp 53\% & $\begin{array}{l}\text { Fusarium spp } 12 \% \\
\text { Penicillium spp } 12 \%\end{array}$ \\
\hline India, Madras & Venugopal $\left.\right|^{38} t$ & 1989 & 322 & & Aspergillus spp $64 \%$ & Acremonium spp $8.4 \%$ \\
\hline India, Tiruchiripalli & Thomas $^{12}$ & 1986 & 774 & $32 \%$ & Fusarium spp $38 \%$ & Aspergillus spp 30\% \\
\hline India, Madurai & Rahman $^{39}$ & 1997 & 58 & & Fusarium spp 38\% & Aspergillus spp $17 \%$ \\
\hline India, Madurai & Srinavasan ${ }^{7} \dagger$ & 1997 & 434 & $35 \%$ & Fusarium spp $47 \%$ & Aspergillus spp $16 \%$ \\
\hline Sri Lanka & Gonawardena ${ }^{40}$ & 1994 & 66 & $33 \%$ & Aspergillus spp $18 \%$ & single isolates \\
\hline Thailand & Imwidthaya $a^{41}$ & 1995 & 145 & $25 \% \ddagger$ & Aspergillus spp $34 \%$ & Fusarium spp $26 \%$ \\
\hline Singapore & Wong 42 $^{2}$ & 1997 & 29 & & Fusarium spp $52 \%$ & A flavus $17 \%$ \\
\hline Hong Kong & Houang ${ }^{43}$ & 2001 & 223 & $2 \%$ & Fusarium spp $60 \%$ & \\
\hline $\begin{array}{l}\text { †Percentages of fung } \\
\text { total number of corne } \\
\text { are cultured from the } \\
\ddagger N \text { figures stated. }\end{array}$ & $\begin{array}{l}\text { s cases ha } \\
\text { reported, } \mathrm{n}\end{array}$ & - & nsitiv & mhers & $\begin{array}{l}\text { g fungal keratitis. } \\
\text { on of fungal corneal } \\
\text { s can be misleadin }\end{array}$ & $\begin{array}{l}\text { s as a percentage of the } \\
\text { ticularly if multiple isolate }\end{array}$ \\
\hline
\end{tabular}

of corneal ulcers followed by staphylococci $(26.8 \%)$ and pseudomonads (14.9\%). In both countries more than $80 \%$ of bacterial isolates were represented by these three genera.

Fusarium spp and Aspergillus spp were isolated from $61 \%$ of all fungal infections and comprised $83 \%$ of identified fungal isolates (Table 3). Although Fusarium species were the most prevalent fungal pathogens reported in Ghana, differences in the spectra of fungi were observed between the participating centres. In Accra (southern Ghana), 63\% (27/43) of fungi isolated were Fusarium spp compared with $31.3 \%$ (15/48) at Bawku Hospital (northern Ghana), where a greater variety of fungi were isolated. Lasiodiplodia theobromae was the third commonest fungal isolate in Ghana. In India a greater number, and diversity, of dematiaceous moulds were cultured; Curvularia species were most frequently isolated.

\section{DISCUSSION}

Fungi were identified as the principal aetiological agent of corneal ulceration: $44 \%$ and $37.6 \%$ of cases in India and
Ghana. Earlier studies in the same regions reported a similarly high proportion of fungal keratitis. ${ }^{6}{ }^{12} \mathrm{~A}$ review of the literature shows that there are distinct patterns of geographical variation in the aetiology of suppurative keratitis and considerable variation in the proportion due to fungi has been documented (Table 4). The proportion of corneal ulcers caused by filamentous fungi increases towards tropical latitudes (Fig 1). In more temperate climates, fungal ulcers are uncommon and are more frequently associated with Candida species than filamentous fungi. ${ }^{21-24}$ Houang $e t ~ a l^{43}$ reviewed the relation of fungal keratitis to climate concluding that, although a higher incidence of fungal keratitis could be expected in countries with similar annual rainfall and temperature range, this was not always so and was also dependent on the extent of urbanisation.

Aspergillus spp and Fusarium spp are the most frequently reported fungal pathogens isolated from cases of fungal keratitis in the tropics. ${ }^{5}$ In both Ghana and south India the most commonly isolated fungal pathogens in the current series 


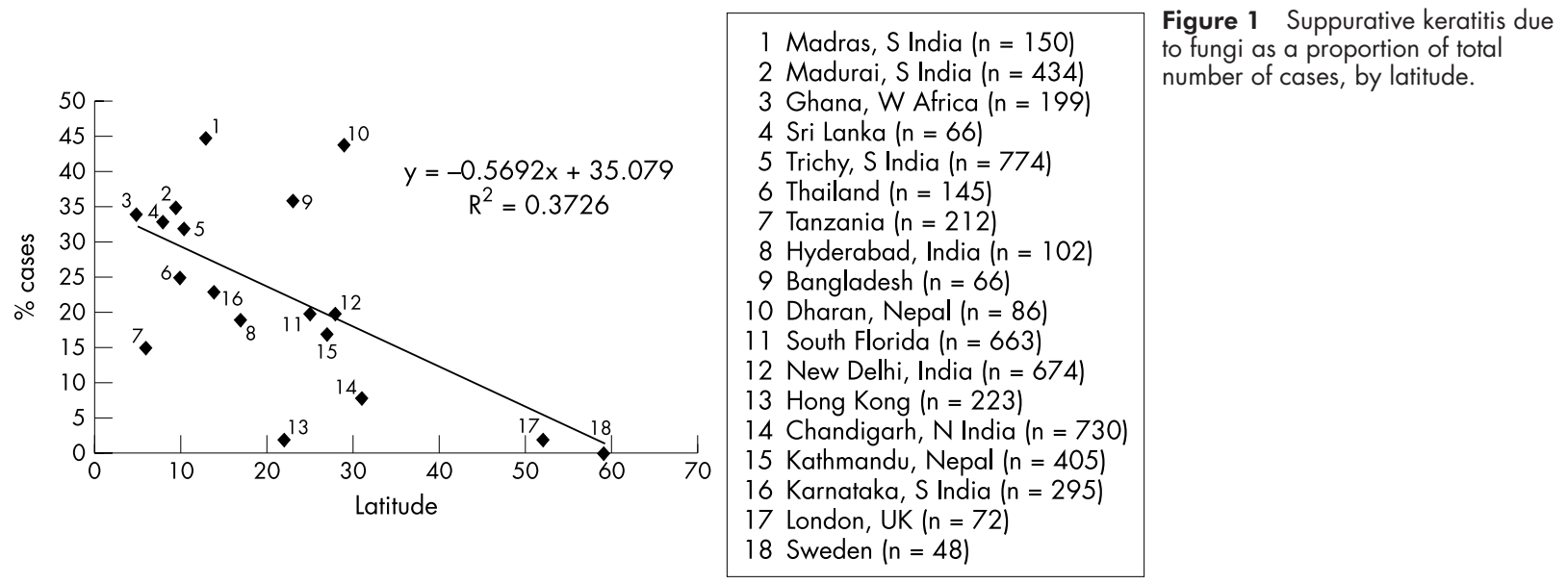

were Fusarium spp. Other studies in south India have reported Fusarium spp to be more common than Aspergillus species. Fusarium spp have also been found to be the principal fungal pathogen in Florida, Paraguay, Nigeria, Tanzania, Hong Kong, and Singapore (Table 4). Aspergillus species predominate in northern India, Nepal, and Bangladesh. ${ }^{1}{ }^{13} 3234$ This phenomenon may be explained by differences in climate and the natural environment. A similar pattern was also observed in Ghana. Although Fusarium spp were the most commonly isolated fungi at all of the centres in Ghana, moulds with enteroblastic conidia adhering in dry chains-for example Aspergillus spp and Paecilomyces spp, were more frequently isolated from patients in the north of the country where the environment is drier and dustier, than in the more humid south. As observed by Khairallah ${ }^{26}$ the high proportion of corneal infections caused by Aspergillus spp in drier climes may be due to the fact that spores of Aspergillus spp can tolerate hot, dry weather conditions. Aspergillus spp also predominate in more temperate latitudes.

A significant increase in the number of reported cases of suppurative keratitis was observed during the harvest period and windy seasons. However, the proportion of corneal ulcers due to fungi remained consistently high throughout the year. Other authors have made similar observations, noting an increase in cases of fungal keratitis during the dry, windy seasons compared with the wet, humid months of the year. ${ }^{419}$ This trend is likely to be a direct consequence of increased agricultural activity before and immediately following the rains. Some studies have reported an increase during the hot and humid months. ${ }^{835}$

The majority of filamentous fungi associated with corneal ulceration in the tropics are saprobic, thermophilic moulds that are found widely in this environment. These are ubiquitous in the soil and vegetation. Fusarium species are common plant pathogens, particularly of cereal crops or saprophytes of plant debris and are found in soil. ${ }^{44}$ The aspergilli are ubiquitous and have been found almost everywhere on every conceivable type of substrate, including soil and decaying organic debris. Some of the less common isolates such as Bipolaris spp and Exserohilum spp are pathogens of grasses. Curvularia spp mostly occur on dead plant material. ${ }^{44}$ Although injury by vegetable matter is considered to be predictive for fungal keratitis, in this study fungal corneal ulcers were more often preceded by dust or mud particles in the eye.

A shift in the predominant bacterial pathogens was observed when compared with earlier findings. In Ghana, $>50 \%$ of bacterial isolates were Pseudomonas species compared with $27 \%$ of isolates in a previous study by Hagan et al. ${ }^{6}$ There is a paucity of information in the literature regarding the aetiology of bacterial corneal ulcers in sub-Saharan tropical Africa and, therefore, comparisons are only possible with similar geographical and climatic regions outside the continent of Africa. Pseudomonas species were identified as the commonest bacterial isolate in a study of 142 cases of suppurative keratitis in Bangladesh in a study by Dunlop et al and also by Williams et al, who found that $40 \%$ of bacterial isolates were Pseudomonas spp. ${ }^{43}$ A predominance of Pseudomonas species has been reported in Hong Kong, Florida, and Paraguay. ${ }^{19} 2543$ In reports from Nepal and south India, Gram positive cocci have been reported as the primary cause of bacterial keratitis. ${ }^{179}$ In this study, Gram positive cocci accounted for the majority (74\%) of bacterial isolates in India, as found previously by Thomas et al. ${ }^{12}$ The proportion of bacterial ulcers caused by Streptococcus spp increased from 18.5\% (1986) to $46.8 \%$ in this study. Similar diagnostic criteria were used in the previous study and, therefore, the trend may be attributable to a genuine change of bacterial flora within the geographical area, as influenced by climate and environment.

Traditional diagnostic laboratory methods, including microscopy and culture may be negative despite a clear clinical presentation of suppurative keratitis. This was true in $50 \%$ and $31 \%$ of cases in Ghana and India, respectively. This may be due to difficulty in obtaining sufficient corneal material for conventional investigation. This applies particularly to large, late stage ulcers, because of the risk of perforation and, conversely, early stage, small ulcers from which little material is available. It is imperative that the quality and quantity of specimen is optimal for accurate laboratory diagnosis. Self administration of antibiotics by patients before seeking medical attention has been thought to affect the recovery of organisms in culture. ${ }^{4}$ It is possible culture positivity correlated with inappropriate antibiotic usage.

Although there were a high proportion of corneal ulcers in Ghana for which the aetiology was not determined, the number of proved fungal ulcers at each of the centres was greater than the number of proved bacterial ulcers. It is therefore not unreasonable to assume that this trend could be extrapolated.

It is usually not possible to determine the significance of bacteria observed by microscopy alone. Small numbers of Gram positive cocci may be contaminants from the lid margin. Conversely, the presence of fungal hyphae in corneal tissue is significant. In agreement with Dunlop et al the sensitivity, specificity, and predictive value of Gram stain microscopy is much higher for fungal ulcers than those caused by bacteria. ${ }^{4}$ In this study $95 \%$ of fungal infections could have been diagnosed based on the findings from microscopy alone. This is an important conclusion, since the majority of rural based clinics in areas where suppurative keratitis is a problem do not have culture facilities but may be able to perform simple microscopy. A wet mount preparation, using lactophenol cotton blue stain, was used as a supplementary stain in this 
study. Where scientific expertise, and/or resources, may be an issue, it is easier to observe fungal hyphae employing this method than using the potassium hydroxide $(\mathrm{KOH})$ technique. Reports into the presence of fungi in the eyes of asymptomatic individuals, have shown that a wide variety of fungi may be transient in the conjunctival sac. This may be the case in as many as $37 \%$ of healthy eyes, thereby discounting the use of single culture. ${ }^{11}$

In conclusion, it is imperative to know the "local" aetiology of keratitis in a particular region. Our comparative study demonstrates that there were differences between two countries with similar tropical climates at the same latitude. Equally, differences were observed within the same country. This is important information with regard to management, as many eye units do not have microscopy or culture facilities. Diagnosis is then dependent on clinical acumen and the treatment provided is, at best, empirical. It is clear that it is important to know the local aetiology, particularly if diagnosis is going to be reliant on clinical signs alone. Changing patterns of disease have also occurred in temperate, developed countries, as exemplified by the increase in keratitis due to Pseudomonas spp and Acanthamoeba spp in recent years. Awareness of changes in aetiology and antimicrobial resistance, when this information is available, are critical to managing keratitis cases.

\section{ACKNOWLEDGEMENTS}

The authors would like to thank the staff of Korle Bu, Bawku, and Agogo hospitals (Ghana) and Musiri, Ariyalur, and Myladthurai hospitals (India) for their assistance during this study. Also, Miss Linda Ficker, Dr Allen Foster, and Dr Elizabeth Wright for their clinical guidance.

\section{Authors' affiliations}

A K Leck, G J Johnson, Department of Infectious and Tropical Diseases, Clinical Research Unit, London School of Hygiene and Tropical Medicine, Keppel Street, London WCIE 7HT, UK

P A Thomas, J Kaliamurthy, M John, C M Kalvathy, C A N Jesudasan, Institute of Ophthalmology, TELC-Joseph Eye Hospital, Tiruchirapalli, South India

M Hagan, E Ackuaku, M J Newman, F S Codjoe, J A Opintan, V

Essuman, Korle Bu Teaching Hospital, Accra, Ghana

\section{REFERENCES}

1 Upadhyay MP, Karmacharya PC, Koirala S, et al. Epidemiologic characteristics, predisposing factors, and etiologic diagnosis of corneal ulceration in Nepal. Am J Ophthalmol 1991;111:92-9.

2 Gonzales CA, Srinivasan M, Whitcher JP, et al. Incidence of corneal ulceration in Madurai District, south India. Ophthalmic Epidemiol 1996;3:159-66.

3 Whitcher JP, Srinivasan M, Upadhyay MP. Corneal blindness: a global perspective. Bull World Health Organ 2001;79:214-21.

4 Dunlop AAS, Wright ED, Howlader SA, et al. Suppurative corneal ulceration in Bangladesh. Aus NZ J Ophthalmol 1994;22:105-10.

5 Thomas PA. Mycotic keratitis - an underestimated mycosis. J Med Vet Mycol 1994;32:235-56

6 Hagan M, Wright E, Newman M, et al. Causes of suppurative keratitis in Ghana. Br J Ophthalmol 1995;79:1024-8.

7 Srinivasan M, Gonzales CA, George C, et al. Epidemiology and etiological diagnoses of corneal ulceration in Madurai, south India. $\mathrm{Br} J$ Ophthalmol 1997;81:965-71.

8 Panda A, Sharma N, Das G, et al. Mycotic keratitis in children: epidemiologic and microbiologic evaluation. Cornea 1997;16:295-9.

9 Khanal B, Kaini KR, Deb M et al. Microbial keratitis in eastern Nepal. Tropical Doctor 2001;31:168-9.

10 Foster CS. Fungal keratitis. Infect Dis Clin N Am 1992;6:851-7.

11 Gugani HC, Talwar RS, Nioku-Obi AN, et al. Mycotic keratitis in Nigeria. A study of 21 cases. Br J Ophthalmol 1976;60:607-13.
12 Thomas PA, Kalavathy CM, Rajasekaran J. Microbial keratitis-a study of 774 cases and review of the literature. J Madras State Ophthalmic Assoc 1986;23:13-21

13 Deshpande SD, Koppikar GV. A study of mycotic keratitis in Mumbai. Indian J Pathol Microbiol 1999:42:81-7.

14 Garg P, Gopinathan U, Choudhary K, et al. Keratomycosis: clinical and microbiologic experience with dematiaceous fungi. Ophthalmology 2000 107:574-80.

15 Jones DB. Initial therapy of suspected microbial corneal ulcers. II. Specific antibiotic therapy based on corneal smears. Surv Ophthalmol 1979;24:97, 105-61.

16 Kunimoto DY, Sharma S, Garg P, et al. Corneal ulceration in the elderly in Hyderabad, south India. Br J Ophthalmol 2000;84:54-9.

17 Coster DJ, Wilhelmus J, Peacock J, et al. Suppurative keratitis in London. The cornea in health and disease. Vlth Congress of the European Society of Ophthalmology 1981;40:395-8.

18 Neumann M, Sjostrand J. Central microbial keratitis in a Swedish city population. A three-year prospective study in Gothenburg. Acta Ophthalmol (Copenh) 1993;71:160-4.

19 Liesegang TJ, Forster RK. Spectrum of microbial keratitis in south Florida. Am J Ophthalmol 1980;90:38-47.

20 Rosa RH, Miller D, Alfonso EC. The changing spectrum of fungal keratitis in south Florida. Ophthalmology 1994;101:1005-13.

21 Tanure MA, Cohen EJ, Sudesh S, et al. Spectrum of fungal keratitis at Wills Eye Hospital Philadelphia, Pennsylvania. Cornea 2000; 19:307-12.

22 Ormerod LD, Hertzmark E, Gomez DS, et al. Epidemiology of microbia keratitis in southern California. A multivariate analysis. Ophthalmology 1987:94:1322-33.

23 Harris DJ Jr, Stulting RD, Waring GO 3rd, et al. Late bacterial and fungal keratitis after corneal transplantation. Spectrum of pathogens, graft survival, and visual prognosis. Ophthalmology 1988;95:1450-7.

24 O'Day DM. Selection of appropriate antifungal therapy. Cornea 1987;6:238-45.

25 Miño de Kaspar H, Zoulek G Paredes ME, et al. Mycotic keratitis in Paraguay. Mycoses 1991;34:251-4.

26 Khairallah SH, Byrne KA, Tabbara KF. Fungal keratitis in Saudi Arabia. Doc Ophthalmol 1992;79:269-76.

27 Carmichael TR, Wolpert $M$, Koornhof HJ. Corneal ulceration at an urban African hospital. Br J Ophthalmol 1985;69:920-6.

28 Mselle J. Fungal keratitis as an indicator of HIV infection in Africa. Trop Doct 1999;29:133-5.

29 Ormerod D. Causation and management of microbial keratitis in subtropical Africa. Ophthalmology 1987;94:1662-8.

30 Chaudhary A, Singh TSK, Lalchandani S, et al. Corneal ulceration and microbial keratitis in Pokhara, Nepal. J Nep Med Assoc 1999;39:18-22

31 Rahman MR, Johnson GJ, Husain R, et al. Randomised trial of $0.2 \%$ chlorhexidine gluconate and $2.5 \%$ natamycin for fungal keratitis in Bangladesh. Br J Ophthalmol 1998;82:919-25.

32 Williams G, McClellan K, Billson F. Suppurative keratitis in rural Bangladesh: the value of gram stain in planning management. Int Ophthalmol 1991;15:131-5.

33 Williams G, Billson F, Husain R, et al. Microbiological diagnosis of suppurative keratitis in Bangladesh. Br J Ophthalmol 1987;71:315-21.

34 Chander J, Sharma A. Prevalence of fungal corneal ulcers in northern India. Infection 1994;22:207-9.

35 Mahajan VM. Ulcerative keratitis: an analysis of laboratory data in 674 cases. J Ocul Ther Surg 1985;4:138-41.

36 Kotigadde S, Ballal M, Jyothirlatha, et al. Mycotic keratitis: a study in coastal Karnataka. Indian J Ophthalmol 1992;40:31-3.

37 Sundaram BM, Badrinath S, Subramanian S. Studies on mycotic keratitis. Mycoses 1989:32:568-72.

38 Venugopal PL, Venugopal TL, Gomathi A, et al. Mycotic keratitis in Madras. Indian J Pathol Microbiol 1989;32:190-7.

39 Rahman MR, Minassian DC, Srinivasan M, et al. Trial of chlorhexidine gluconate for fungal corneal ulcers. Ophthalmic Epidemiol 1997:4:141-9.

40 Gonawardena SA, Ranasinghe KP, Arseculeratne SN, et al. Survey of mycotic and bacterial keratitis in Sri Lanka. Mycopathologia 1994; 127:77-81

41 Imwidthaya P. Mycotic keratitis in Thailand. J Med Vet Mycol 1995:33:81-2.

42 Wong TY, Fong KS, Tan DTH. Clinical and microbial spectrum of fungal keratitis in Singapore: a 5-year retrospective study. Int Ophthalmol 1997;21:127-30

43 Houang E, Lam D, Fan D, et al. Microbial keratitis in Hong Kong: relationship to climate, environment and contact-lens disinfection. Trans $R$ Soc Trop Med Hyg 2001:95:361-7.

44 De Hoog GS, Guarro J, Gené J, et al. Atlas of clinical fungi. 2nd ed. 2000:30-5. 